\title{
Winter's Discontent: Market Failure and Consumer Welfare
}

Mark Green and Beverly Moore, Jr.*

We are gratified that a critic like Mr. Winter, who has labored under the misimpression that we were advocates of more regulation, now understands and agrees with our previously articulated view about the monopoly-making tendencies of past and present economic regulation. His reply, however, passes beyond agreement with what was said to disparagement of what was not. The designated topic of economic regulation and restrictions precluded extensive discussion of health and safety regulation. But since Mr. Winter now focuses on health and safety regulation, we turn to that topic.

\section{I}

Mr. Winter's critique, as befits his orientation, is that of the law professor before a first year class: asking questions, not answering them; deploying theories, not facts. Instead of health and safety regulation, he doggedly opts for a free market solution to consumer problems. Despite his many theoretic contentions-the key one being that consumer sovereignty is alive and well-Mr. Winter offers hardly any supporting studies or data. Let us take two examples. For all his hypothesizing about the potentially damaging effects of health and safety regulation, one of the few studies he cites is Peltzman's The Benefits and Costs of New Drug Regulation.2 That study purports to demonstrate that the FDA requirement that new drugs be proven safe before being allowed on the market, in Mr. Winter's words, "significantly impedes the rate of introduction of new drugs and thus prevents beneficial as well as harmful drugs from entering the market."3 It has been thoroughly discredited by medical authorities, who concur that while the FDA has blocked some dangerous drugs, it has not thwarted any

* B.A. University of North Carolina, 1967; J.D., Harvard Law School, 1970. Due to Mr. Nader's previously scheduled commitments during the time available for a rebuttal, the Journal invited Mr. Moore to join Mr. Mark Green in the following response to Mr. Winter.

1. See R. Fellameth, The Interstate Commerce Omission (1970); Mf. Green, B. Moone \& B. Wasserstein, 2 The Closed Enterprise Systent '(Prelim. cd. 1971).

2. S. Peltzaran, The Benefits and Costs of New Drte Reculation (1972).

3. Winter, Economic Regulation vs. Competition: Ralph Nader and Creeping Capilal. ism, 82 YALE L.J. 891 (1973) [hereinafter cited as Winter]. 
safe and substantial ones. ${ }^{4}$ Still, due to necessitous proponents like Mr. Winter, Peltzman's study retains signs of life.

Second, Mr. Winter argues that consumers "may" be better off with industrial concentration, rather than with more structural competition, due to large scale economies." Almost anything "may" be true, but what is the weight of the evidence? A large body of empirical data relates industrial concentration to monopoly profits, ${ }^{6}$ excessive executive compensation, ${ }^{7}$ internal inefficiency, ${ }^{8}$ technological sloth, ${ }^{0}$ and

4. Peltzman shows that the number of "new chemical entities" in drugs declined from 43.5 per year during the pre-regulation $1956-1962$ period to 16.2 per year during the 1969 . 1970 period; he attributes the decline to the effects of mandatory pre-market sifety clear. ance. S. Peltzman, The Benefits and Costs of New Drug Regulation (1972). The number of "new chemical entities" introduced, however, bears no relation to significant advances in medicine. Any slight molecular modification of an existing compound quallfies as a "new chemical entity." Actually, the number of significant therapeutic advances in new drugs has been about the same during the period of regulation as before. $H$. Dowling, MEdicines FOR MAN 99 (1970) places the number of important therapeutic ad. vances at three to four per year for both the regulation and pre-regulation periods. The analysis of Dr. Henry E. Simmons, Director of the F.D.A.'s Bureau of Drugs, indicates that the average yearly number of important therapeutic advances was 6.86 during the 1950-1963 pre-regulation period and 5.7 during the $1964-1971$ period. Hearings on Competitive Problems in the Drtg Industry before the Monopoly Subcommittee of the Senalc: Select Committee on Small Business, 93d Cong., lst Sess. (Feb. 5, 1973). The "new chemical entities" statistic on which Peltzman relies thus reflects drug firms' successes in differentiating their products and in carving out new patent monopolies, not in reducing the toll of illness.

Even assuming, arguendo, that Peltzman's thesis were correct, the appropriate remedy would not be to drop the testing requirement, but rather to permit the marketing of promising drugs, with effective warnings, pending the completion of their tests, provided that the producers be made liable for any injuries to consumers in the interim. In fact, this is the procedure that the FDA often follows, $i d$., except that no provision for ultimate tort liability is provided. In addition, FDA safety guidelines do not reguire that new drugs be free of all harmful side-effects. Injuries to small percentages of the uscr population from drugs deemed by the agency to be "safe" are often cxplicitly recognized. To abolish the requirement that drugs be proven safe would surely increase the risk of numerous thalidomide-type disasters. Even now, an estimated three to five percent of all admissions to medical services and as many as 30,000 hospital patient deaths annually result primarily from adverse drug reactions. Hurwitz, Admissions to Hospital Due to Drugs, 1 BRIT. MED. J. 539 (1969); Seidl, et al., Studies on the Epidemiology of Adverse Drug Reactions III: Reactions in Patients on a General Medical Seruice, 119 BuLl. Jouls Hopkins Hosp. 299 (1966); unpublished data supplied by Dr. Milton Silverman and Dr. Philip R. Lee, University of California at San Francisco. The need for more effective drug regulation rather than abandonment of present efforts is underscored by the 1.5 million cases annually of adverse reactions to $\mathrm{FDA}$ approved drugs, Cluff, Problems with Drugs, Procendincs of THE Conference on Continuing Education for Pilystains IN THE USE OF DRUGS 9 (Nat'l Academy of Sciences, 1969), seventy to eighty percent of which are preventable. Melmon, Preventable Drug Reactions-Causes and Cures, 284 NEw ENGLAND MED. J. 1361 (1971).

5. See Winter 892 .

6. See generally Weiss, Quantitative Studies in Industrial Organization in FrontuEns of QuantiTative Economics 363-71 (M. Intriligator ed. 1972).

7. See, e.g., Williamson, Managerial Discretion and Business Behavior, $58 \mathrm{AM}$. ECoN. REV. 1032, 1042-47 (1963).

8. See, e.g., id. at 1051-53; Liebenstein, Allocative Efficiency vs. 'X-Efficiency' 56 AM. ECoN. Rev. 392 (1966); W. Shepherd, MARKet POWER AND EConomic WelFARE 195.96 (1970). Cf. Alchian \& Kessel, Competition, Monopoly, and the Pursuit of Money, in NAT'L BUREAU OF ECONOMIC RESEARCH, AsPECTS OF LABOR EcoNomics (1962). Within threc months after workers in the Kaiser Steel Company's Fontana, California plant werc told of an impending shutdown due to competition from Japanese imports, productivity rose by 32.1 percent. Washington Post, Feb. 11, 1978, $\S$ E, at 5, col. 1 .

9. See generally J. BLAIR, ECONOMIC ConcENTRATION 199-254 (1972). 
employment discrimination. ${ }^{10}$ Conceding that the power of a pure monopolist to price above marginal cost will result in output restriction and resource misallocation, Mr. Winter nevertheless concludes that "until one knows what efficiency gains-reduction of marginal cost -are produced through economies of scale, the factual conclusion that consumers suffer from concentration cannot be made." 11 Yet the available data indicate that the large majority of leading firms in concentrated industries are far larger than would be necessary to exploit any economies of scale. ${ }^{12}$ This is a crucial point, for the original article was careful to recommend that economic deconcentration precede economic deregulation where necessary to make the market viably competitive. ${ }^{13}$

10. Shepherd, Market Power and Racial Discrimination in White-Collar Employment, 14 ANTrRRUST BuLL. 141 (1969).

11. Winter 899.

12. See, e.g., J. Bain, Barriers to New CoMretrtion 111 (1956); Saving, Estimation of Optimum Size of Plant by the Survivor Technigue, 75 Q.J. Ecos. 569 (1961); Sherman \&. Tollison, Public Policy Toward Oligopoly: Dissolution and Scale Economies, 4 ANTrTRUST L. \& ECON. REv. 77 (1971); Esposito, Noel \& Esposito, Dissolution and Seale Economies: Additional Estimates and Analysis, 5 ANTmust L. \&. Ecos. REv. 103 (1971). See also Kottke, Dissolution and Scale Economies: A Comment, 5 ANTrusust L. \& Ecos. REv. 55 (1972). Even in the few industries where deconcentration might impose higher costs through suboptimal scale economies, the countervailing gains from improved resource allocation, increased internal efficiency and technological progressivity, and redistribution of monopoly profits and excessive compensation must be considered before rejecting divestiture on economic efficiency grounds.

Mr. Winter errs in three other respects in describing our antitrust views. "A consistent, principled, assault on concentration," he states, "would thus involve a frontal attack on vast areas of the economy and not just on certain highly visible, and politically vulnerable, industries." Winter 898-99. Never have we advocated deconcentration only for "highly visible" or "politically vulnerable" industries. Except for a minimum industry size requirement dictated by the consideration of administrative feasibility-ve have suggested annual sales of $\$ 50$ million-we have urged deconcentration of all concentrated industries. M. Green, B. Moore \& B. WAsserstens, The Closed ENTERprise Systes 303-13 (1972). Given that one must begin somewhere, and with limited resources, a deconcentration campaign should proceed first against those industries which involve the largest markets and the highest degrees of concentration.

It is also said that our deconcentration proposals would require "the courts to determine the optimal size or number of firms in an industry." W'inter 899 . On the contrary, our objective of reducing four-firm concentration ratios to below fifty percent and eight-firm concentration ratios to below seventy percent leaves wide latitude for the number and size of the firms operating within those parameters.

In addition, it is asserted that "[s]o long as government does not restrict entry, any concentration not based on efficiency will ultimately be destrojed by market forces." Id. But how long should injured consumers be required to wait? Imperfections in the market insulate concentrated industries from competitive entry. Such imperfections include entry barriers associated with product differentiation (see Comanor \& Wilson. Advertising, Mrarket Structure, and Performance, 49 REv. Ecos. \& STAT. 423 (1967)), and excess capacity (see Wenders, Excess Capacily as a Barrier to Entry, $20 \mathrm{~J}$. IND. Ecos. 14 (1971)), and imperfections in the capital market exacerbated by the size of vertically integrated firms (see Hall \&. Weiss, Firm Size and Profitability, 49 REv. Ecos. \& STAT. 319 (1967)). Mr. Winter's basic contention is belied by the persistence of high levels of concentration in particular industries (see REPORT OF THE WHITE HOUSE TASK FOnCE ON ANTITRUST PoLICY 6 (1968)) and the overall economy (see W. Shepherd, supra note 7, at 106) coupled with the general absence of justifying economies of scalc.

13. Green \& Nader, Economic Regulation vs. Competition: Uncle Sam the Monopoly Man, 82 YALE L.J. 871 (1973) [hereinafter cited as Nader]. 
II

Perhaps the best example of the empirical weakness of Mr. Winter's argument concerns consumer information and consumer sovereignty. He contends that our proposals for increased business disclosures, enabling consumers to compare product values and to purchase morc intelligently, merely reflect our personal preferences, "imposing on consumers the cost of collecting and transmitting information which they find has little value." ${ }^{1+}$ He provides no examples of such useless information; nor, apparently, does he feel them necessary, for he writes: "[c]ompetition rewards those who provide the information desired by consumers." 15 Any information not generated by competitive forces is characterized as a costly and useless surplus (absent some special showing of free rider effects or, in the case of cigarettes, addiction). ${ }^{16}$ In Mr. Winter's view there can be no market failure to provide optimal consumer information. Advertising and other seller promotional materials do the job nicely.

To assess this thesis, we analyzed the content of approximately 1,000 network television food commercials. These typically provided consumers with such valuable tips as:

"Mm good!"

"The secret sauce kids never get tired of"

"No dog food ever looked like that before"

"Lip smacking, whip cracking, patty whacking"

"It's the real thing"

"Anyone can be a Frito bandito"

In general, the foods with the least nutritional value were the most heavily advertised.17 Yet the nutrition "information" contained in such ads often consisted of such vague assertions as "nutritious," "fully balanced," "nourishing," "loaded with energy," or "fortified with body-building vitamins and iron." Information was never provided about the disadvantages or weaknesses of the advertised products. Numerous claims were made that the advertised product was "better" or "different" or "unique" in some manner, but rarely were compet-

14. See Winter 890 .

15. Id.

16. See id.

17. This is in part true because snacks, candies, and highly processed convenience items are more easily differentiated than more nutritious traditional staples. Thus, in a story rejoicing over the gains of soft drinks at the expense of competing beverages, the 1971-1972 SofT Drink ANNUAs. ManUal bluntly attributed much of the decline in per capita milk consumption "to the fact that the milk industry simply docs not promote its products in an aggressive manner." $I d$. at 63. 
ing products faulted for their shortcomings, and never were they identified by name. ${ }^{18}$

The theoretical justification for such advertising and promotional expenditures is, surely, to supply information that supports consumer sovereignty. Instead, producer sovereignty is the actual objective and result. Advertising does not function in an adversary manner. It presents the pros, not the cons. ${ }^{19}$ It fosters no true marketplace of ideas. That consumers may accept the advertised products does not mean that they would not prefer other products-alternatives presently available in the market, about which the competitive process does not generate optimal information, and alternatives only potentially available about which there is no information. And why should it be otherwise? Producers, operating in a world in which consumers have less product information than they, can opt for the easier and less risky path of selling what consumers will accept rather than what they would prefer. To assume that the market generates all the cost-effective information that consumers need to maximize the value of their purchasing power is to mistake a fanciful model for the real world. ${ }^{20}$

18. In fact, until 1972 , television networks refused to brozdast commercials which criticized competing products by name. In that year, they were persuaded by the FTC to change their policy. Subsequently, advertisements for only a handful of products have specifically referred to competing brands.

19. See Washington Post, Jan. 31, 1973, $\$$ B, at 1, col. 1; N.Y. Times, Jan. 21, 1973, $\$$ F, at 15, col. 1. Cf. Scitovsky, Ignorance as a Source of Oligopoly Pouer, $\mathbf{1 0}$ As. Ecos. Rev. Papers and Procendings 48 (1950).

20. Since it is convenient for economists to assume perfect knowledge, little attention has been paid to the subject of consumer utility maximization. If consumers vere adequately informed by the forces of competition, we would expect that the higher the price, the higher the quality; the lower the price, the lower the quality. The correlation, however, between the Consumers Union product quality ratings and the prices of the rated products is only approximately .35. Oxenfelde, Consumer Rinouledge: Its II eas. urement and Extent, 32 REv. EcoN. \& Srat. 300 (1950); Morris \& Bronson, The Chaos of Competition Indicated by Consumers Reports, $33 \mathrm{~J}$. MAARETINe 26 (1969). When the sample is limited to product classes offering eight or more brand alternatives with interbrand price spreads of at least fifty percent the median price-quality correlation plummets to .20. Friedman, Quality and Price Considerations in Rational Consumer Decision-NIaling. $1 \mathrm{~J}$. Consumer AfFairs 13, 17 (1966). There are many examples of this phenomenon. Nationally advertised supermarket items sell for about twenty percent more than store brands even though both products are virtually identical and ofien manufactured by the same company. Nat'l Comm'n on Food Marketing. Special Studies in Food Marketing 47,65 Tech. Study No. 10 (1966). In another study, there was a 170 percent spread between the lowest and highest priced life insurance policies of comparable value, with many of the largest and best known companies policies being the most expensive. PExN. INSURANCe CoMm'N, Shoppers' GuIde to Life Insurance 14,15 (1972). Pennsylvania Insurance Commissioner Herbert $S$. Dennenberg estimates that informed consumers could save $\$ 3$ billion annually in premiums if they shopped for and actually purchased the best buys. Washington Post, Miay 25, 1972, at $\mathrm{xx}$, col. $\mathrm{B1}$.

In his analysis, supra, of thirty consumer product classes, Alfred R. Oxenfeldt assumed, as the unavailability of data forced him to assume, that the product sample vias random, that brand sales were equal, and that Consumers Union product quality ratings mirrored actual consumer evaluations. He then projected that consumers purchasing the "best buy" brands could have increased the value of their purchasing power by fully fifty percent.

No doubt the market does generate some useful consumer information, but it also 
Still, Mr. Winter insists that "consumer choice" is the "plausible explanation" for such phenomena as the presence of ornamental bump. ers and the superior profitability of white bread compared to more nutritious varieties. ${ }^{21}$ But were consumers ever given the choice between a functional bumper able to withstand a five-mile-per-hour collision without damage at an extra cost of $\$ 100$ (to use the auto industry's dubiously high estimate), ${ }^{22}$ and an ornamental bumper with a $\$ 332$ repair bill for each such collision? ${ }^{23}$ Since auto firms promoted and offered only the latter, it is circular to argue that consumers "chose" it over the former. Similarly, Mr. Winter offers no evidence that consumers who "choose" white bread over whole wheat bread are consciously aware that the milling process depletes white bread of 15.9-86.3 percent of 20 essential vitamins and minerals, with most losses in the higher range, while "enrichment" partially replaces only four of these nutrients. ${ }^{24}$ Indeed, the available evidence contradicts his contention..$^{25}$

If sellers fail to provide optimum consumer information, Mr. Winter assumes that entrepreneurs will "establish independent testing organizations where the value of information to consumers is greater than the cost of collection and transmittal." ${ }^{26}$ But practical difficulties, such as manufacturers' resistance to disclosure, argue against reliance

produces much puffery and deception. A large proportion of advertising claims cannot be substantiated by sellers. Cf., e.g., STAFf of Senate CoMmerce Commitree, 921 Conc., 2D Sess., Retort to the Federal Trade Comm'N ON THE Ad Substantiation prockas (Comm. Print. 1972). On balance, the evidence supports a presumption, contrary to that asserted by Mr. Winter, that the market functions to minimize consumer sovercignty relative to independent, non-seller sources of consumer information.

21. Winter 896.

22. Hearings on Automobile Insurance Reform and Cost Savings Before the Senate Commerce Committee, 92d Cong., 1st Sess., pt. 3, at 1225 (1971). In contrast to Ford's $\$ 100$ cost estimate, Paul and Douglas Taylor, a father and son cngincering team, demon. strated a bumper resistant to damage at five $\mathrm{mph}$ that they were willing to sell to auto companies at $\$ 25$. Id. at 1421-22.

23. This was the average repair bill for the 1971 Chevrolet Impala, Ford Galaxic, Plymouth Fury I, and AMC Ambassador, test crashed into a stationary barrier by the Insurance Institute for Highway Safety. Contrary to Mr. Winter's implication, Depart. ment of Transportation studies demonstrate the cost-effectiveness of bumper standards. National Highway Traffic Safety Adm., AN Economic Analysis of trie Exterior Pro. TECTION STANDARDS, FMVSS-215 (1971). In fact, the statute requires that government bum!. per standards be cost effective. 15 U.S.A. $\$ 1912$ (b)(1) (Supp. 1973).

24. Schroeder, Losses of Vitamins and Trace Minerals Resulting from Processing and Preservation of Foods, 24 AM. J. Clin. Nutrition 562, 567, 569 (1971).

25. Experiments with nutritional labeling programs indicate that consumers do sc. lect more nutritious foods when supplied with the necessary nutrient composition in. formation. Stokes, The Consumer Research Institute's Nutrient Labeling Research Pro. gram, 27 Food DRug Cosmeric L.J. 249 (1972); Dep't of Health, Education \& Welfare, Nutrition Labeling, 37 Fed. Reg. 6493 (1972). With respect to the specific case posed by Mr. Winter, the Washington, D.C., area Giant food chain's sales of whole wheat bread increased from 400 to 1700 loaves per day after its institution of an experimcntal nu. tritional labeling program. Information supplied by the office of Esther Peterson, Giant
consumer affairs consultant.

26. Winter 900 . 
on this assumption. More importantly, information contained in a publication like Consumer Reports is denied access to the most efficient channels of communication available to sellers, through advertising, packaging, and point of purchase. Consumers Union would be unable to compel payment from consumers benefiting from data disseminated in this manner. ${ }^{27}$ Consequently, we propose that independent information be funnelled to consumers through these efficient channels. We advocate free counter-advertising from a diversity of nongovernmental groups, grading of products' performance characteristics and rating of the quality of consumer services (not unlike the government's defining of weights and measures, which Mr. Winter approves). ${ }^{28}$ We would also provide labeling which forces clear and effective disclosure of such information as nutrient content, ingredient percentages, price per unit, predicted average useful life and repair, safety hazards, and warranty terms. "Consumer sovereignty" might then be more reality than homily.

\section{III}

The issue is perhaps best joined in the category of safely regulation. Mr. Winter says that we "fail to justify safety regulation on grounds of true market failure." ${ }^{23}$ This is clearly incorrect, as the article specifically says that "[s]afety regulation explicitly assumes that the market will not adequately protect consumers against certain product hazards." 30 Just as economic regulation is justified by market incapacity (natural monopoly), so safety regulation is necessary when the marketplace fails to encourage the manufacture of optimally safe products. This may occur under various conditions including the following: (l) when the users do not fully control purchases (e.g., the doctor, not

27. One disadvantage faced by an organization such as Consumers Union is corporate credibility resulting from image building via institutional advertising, e.g." "Trust Texaco," and from deliberate attempts to exploit consumers' gullibility' and to direet consumer attention away from the most relevant product characteristics. For example, the All-American image projected by food manufacturers' markcting suricys unanimously indicate that most housewives believe family diets to be nutritionally adequate. Bauman, Problems of Researching and Marketing Fortified Foods and Its Implications on Consumption Trends, Council on Foods ANd Nutrition, AMerican MED. Ass'N, Srysposium on Vitamins and Minerals in Processed Foons 236 (1971), even though other surveys demonstrate that there are substantial nutritional deficiencies among all segments of the population, United States Dep't of Healti, Education and Welfare, TeN State Nutrition Survey 1968-1970 (1972); United States Dep't of Acriculture, Dietany Levels of Households in the United States, Spring, 1965, at 6, 9 (1969); Davis, Gershoff \& Gamble, Review of Studies of J'itamin and Mineral Nutrition in the United States (1957-1958), 1 J. Nutrmion Ed. 41 (Supp. 1, 1969).

28. See Winter 900.

29. Id. at 896 .

30. Nader 885 . 
the patient-consumer, decides what drugs will be taken); (2) when the producer has little incentive to produce a safe product because consumers cannot judge safety factors (the average consumer cannot determine how much DES is in his meat, or how much radiation is being emitted from his medical x-ray); and (3) when manufacturers have an interest in producing unsafe or easily damageable products (auto firms have a lucrative parts market). The original article says that safety regulation is warranted under such conditions because "it is better to prevent consumer harm than compensate it later." 31 Winter would insist on an additional condition: that "compensation is in fact inadequate in the case of the particular product." ${ }^{32}$ This condition almost always prevails: the tort victim's ability to collect is persistently undermined by the difficulty of calculating damages, imperfect substantive liability rules, restrictions on class actions, dilatory practices of defendant corporations, "ethical" prohibitions against lawyers informing consumers of their right to sue, ${ }^{33}$ similar rules against lawyers' financing and purchasing ${ }^{34}$ consumer causes of action, and the general high cost of legal representation. How often do the victims of food poison. ing-an illness ranked second only to the common cold in frequency by many experts ${ }^{35}$-recover damages from the responsible restaurant, food processor, or other source? The National Highway Traffic Safety Administration has placed the societal cost of 1971 motor vehicle accidents at $\$ 46$ billion. ${ }^{36}$ Yet insurance payments to accident victims in the same year totaled only $\$ 7.1$ billion. ${ }^{37} \mathrm{~A}$ study commissioned by the Department of Transportation found that permanent total disability claimants received only sixteen percent compensation for their average

31. Nader 885 .

32. Winter 895 . He would also require, in simplified language, that the benefits of regulation exceed its costs. Winter 892 . While this is a perfectly reasonable and obvious rule, Mr. Winter's hints that it is not presently followed in health and safety regulation are unimpressive and without documentation. His reference to the Peltzman study is, as noted, completely without merit. See note 5 supra.

33. See Note, The Bar As Trade Association: Economics, Ethics, and the First Amendment, 5 Harv. Civ. Rights-Civ. Lib. L. Rev. 334 (1970).

34. Cf. Schwartz, An Economic Analysis of the Contingent Fee In Personal-Injury Lilt. gation, 22 STAN. L. REv. 1125, 1154 (1970). Imperfections in the capital market have generally precluded the financing of consumer litigation by traditional lending organizations.

35. Fodor, et al., Food Poisoning Occurrences in New York City 1969, 85 PU1. HEAL.TH REP. 1013 (1970).

36. National Highway Traffic Safety AdM., Societal Costs of Motor Vellicle ACcidents, app. B, at 1 (1972).

37. Interview with Dean Sharp, Counsel to the Senate Antitrust and Monopoly Sub. committee of the Senate Judiciary Committee in Washington, D.C., March 10, 1973. Mr. Sharp's estimate is based on projections from Hearings on the Insurance Industry Defore The Antitrust and Monopoly Subcomm. of the Sen. Comm. on the Judiciary, 9lst Cong,, 1st Sess., pt. 17, at 10188 (1969). 
economic losses. ${ }^{38}$ State workmen's compensation systems have produced similar results. ${ }^{39}$ No doubt reform could be instituted to render tort compensation a more effective accident cost internalizer. But until such reforms become reality, some regulatory proxy is necessary to stimulate the cost-effective prevention technologies that producers would adopt if accident costs were internalized. $\mathbf{4 0}$

Mr. Winter misunderstands our statement that "the harm inflicted may simply be unacceptable to its victims," 11 calling it merely one of our "preferences." 42 The original point was twofold. First, an assessment of accident costs must recognize that accidents, especially fatal ones, are not transactions into which the average consumer would willingly enter, even if tort compensation ensured that full compensation for the value of his life were paid for his heirs. ${ }^{+3}$ And second, while it is-logically possible that a regime of education through fatality (in which, for example, consumers would learn, the hard way, which drugs cause deformity) would make the FDA unnecessary, the toll in death and disability due to adverse drug reactions is, simply, unacceptable. To argue otherwise-there is no kinder way to put it-is intellectually brutal. A more humane and cost-effective approach is to prevent this consumer harm rather than either to compensate for it later or to tolerate it as the inevitable price of some macabre "free market" of consumer sovereignty.

Compounding his confusion, Mr. Winter asserts that the unacceptability of accidents to victims "is, save where externalities are present, simply no theory at all." 4 But in this, Mr. Winter fails to realize that accident costs are externalities. Externalities can be divided into two classes. "Externalities external to the industry" are exemplified by automobile air pollution and accidents involving pedestrians. Social costs not reflected in automobile prices are imposed on per-

38. U.S. Dept. of Transportation, Economic Consequences of Automonile Accinevt Injuries (1970); U.S. Dep't of Transportation, Automiobile Pensonal Injury Clisis (1970).

39. See The Report of the Nat'l Commission on State Worharev's Compensition LAws (1972).

40. Mr. Winter's speculation that " $[\mathrm{h}]$ ad Mr. Nader been the force in the fifties that he is today, it is likely that he would have made strange bedfellows with the American auto industry in its battle against the small (and less safe) forcign car," W'inter 896, has already been proven wrong. Mir. Nader and forcign imports were around in the 60s, when imports concerned Detroit far more than in the prior decade: Yet there is no cvidence that safety regulation was manipulated into an anticompctitive cntry barrier.

41. Nader 885 .

42. Winter 896 .

43. Other scholars have recognized that additional compensation should be paid for the involuntary nature of takings. Mfichelman, Property, Utility, and Fairness: Comments on the Ethical Foundations of 'Just Compensation' Law, 80 HARv. L. REv. 1165, 1214 (1967).

44. Winter 895 [emphasis added]. 
sons not parties to the automobile purchase transaction. On the other hand, "externalities internal to the industry" involve social costs imposed by products upon their own consumers-e.g., the accident victim whose mishap results from safety defects in his own automo. bile, or the person whose nutritional deficiencies and attendant aclverse health consequences result from the food he eats. In theory, if consumers had perfect knowledge of these risks, they would adjust their purchases to a level of demand at a market price which included the cost of insurance against such risks; there would then be no resource misallocation. ${ }^{45}$ But again theory stumbles on practical fact: Consumers have neither the omniscience nor the unlimited shopping time so blithely assumed.48

Even if consumers did possess perfect knowledge of product hazards, so that resource misallocation would be avoided, it would nevertheless be reasonable to compel manufacturers to avoid externalities internal to the industry. The objective here is to reduce the sum of accident and costs that society must bear. Consumers already have a strong personal stake in avoiding harm to themselves. Producers are in the best position to reduce the costs of accidents through changes in product design or effectively communicated use directions. ${ }^{47}$ The burden of developing and introducing the most cost-effective accident prevention measures technologically possible should therefore be imposed by law upon producers. Firms would be encouraged by the profit motive to develop and adopt cost-effective accident prevention technology in order to avoid the higher costs, higher prices, and lower sales and profits that full internalization would cause.

Full internalization might increase the price of products to reflect their accident costs, causing a decline in sales. But profits would not suffer if the costs of accident prevention technology were less than the

45. E.g., E.J. Mishan, Cost-Benefit ANalysis 164-66 (1971).

46. Even Richard Posner, Mr. Winter's ideological ally, notes as a special case of market failure to generate optimal consumer information, that a seller might avoid inform. ing consumers that a competing product is less safe than his own for fear of implying that his own product is at all unsafe. Posner, Strict Liability: A Comment, $2 \mathrm{~J}$. LEGAt StUdies 205, 211 (1973).

47. Posner argues for a negligence, rather than a strict liability, standard by which: the cost of unavoidable accidents is borne by the victims of accidents. They can re. duce this cost in the long run by financing research into and development of costjustified measures by which to protect themselves. The victims will not themselves organize for research, but they will provide the market for firms specializing in the development of new safety appliances.

Id. at 209. The flaw in this argument is that there will be an optimal demand for such a new safety appliance market only if consumers first obtain perfect knowledgc of safety risks. For example, seat belts were offered by small independent companies for ycars but Detroit refused to install them. There may be special cases in which consuncrs rather than producers can avoid accidents at least cost, but the burden of proof should be placed upon those arguing for such a result. 
increased price increment associated with internalization. For example, although bumpers sustaining little damage at ten-miles-perhour crashes were once considered unduly costly, their development suddenly became far more technologically feasible after firms were compelled to build more crash-worthy bumpers. This point Mr. Winter fails to appreciate. He wrongly assumes firms' continued technological indifference to safety innovations, following enforcement of safety regulation..$^{48}$

Mr. Winter concedes that externalities external to the industry do exist and that they would, at times, justify regulation. ${ }^{10}$ But once again he backpeddles. He raises the specter of psychic harm resulting from the mere thought of others watching obscene movies. ${ }^{50}$ The specter is a sham: Prohibition or compensation would be invoked only for by-products which are substantially and objectively externalities-those which are involuntarily consumed by third parties and which cause cognizable property damage. Auto pollution is such an externality. Obscenity upsetting old ladies is an extremely subjective matter, and to label it an externality would make every person a censor. Moreover, while freedom of speech is a constitutional right, the freedom to pollute is not.

As he does elsewhere, Mr. Winter conjures up a variety of canards in his attempt to demonstrate the irrationality of imposing anti-pollution control devices on cars. As self-appointed spokesman for the rural poor, he argues that they are unfairly taxed by regulation which benefits others. ${ }^{51} \mathrm{He}$ thus employs the well-worn tactic of invoking a small "victim" to justify a larger victimization (not unlike the large

48. Since compulsory seat belt wearing raised by $\mathrm{Mr}$. Winter is not mentioned in the original article, a full discussion of it is inappropriate here. Air bags may soon moot this incipient controversy, since they would avoid the civil liberties issue and vould only work at a time to prevent injury to auto users, a benefit few if any would reject. Briclly, in our view, the compulsory wearing of seat belts would be justified because: a) based on the Australian experience, some 11,500 American lives annually would be saved and car drivers and passengers would grow accustomed to this minor (if that) inconvenience (cf. Washington Post, Mfarch 21, 1972, $\S \mathrm{B}$, at 1, col. 4); b) when $\mathrm{X}$ doesn't wear his or her seat belt, more than just $X$ may be affected: if he is thrown onto the road in an accident or otherwise incapacitated because he is not strapped in, the non-belied rider can cause multiple wrecks by being unable to prevent further collisions; c) every auto death costs $\$ 200,700$ in a variety of hospital, death, and retraining costs and lost-wages, Societal Costs of Motor Vehicle Accidents, supra note 36, app. $D$, at 1 ; and d) if a majority of the motoring public were fully informed of the major reduction in risk to their own safety at such a small cost in inconvenience they would no doubt vote in a referendum for compulsory seat belt wearing, foregoing the immediate gratification of not buckling up in order to realize long-run safety benefits; to assume otherwise is to assume the public's irrationality. Finally, one wonders about the hue and cry over this idea when the FAA has for years required airline passengers to fasten scatbelts during takeoffs and landings.

49. See Winter 898 .

50. See id. at 897 .

51. See id. at 897-98. 
corporate interests who oppose stiffer business controls because they might hurt shareholding widows). Mr. Winter would deny relief to millions of the poor locked in smogged cities because of some thousands who supposedly do not similarly suffer..$^{52}$ Large social and economic savings would result from reduced motor vehicle emissions, which cause at least $\$ 6$ billion annually in damages according to an estimate prepared for the Office of Science and Technology. ${ }^{\text {ba }}$ Strikingly, Mr. Winter does not understand that while auto pollution control devices may impose short-run costs on car owners, they enable net social savings due to decreased property and health damage. And he ignores the basic goal of motor vehicle emissions regulations-to develop a non-polluting alternative to the traditional internal combustion engine. ${ }^{54}$ If manufacturers eventually adopt this alternative, consumers will pay less for their cars and for repairs, and buy less gaso. line, at lower prices (given reduced demand). All of this Mr. Winter ignores, since he preoccupies himself with emission control costs, not emission control savings.

Mr. Winter criticizes our inclusion of antitrust, employment discrimination laws, occupational safety and health requirements and unemployment compensation laws ${ }^{55}$ in the category of enabling legis-

52. In fact, air and rivers polluted by an urban source spill out do affect vast areas, as rural locales outside of Chicago and in Southern California are finding ont. Thic auto manufacturers, in any event, would hardly find it rewarding to produce two dif. ferent cars for various models to service such a small sector as the rural poor. And " two-car strategy is administratively unworkable anyway, given that nearly twenty percent of the population moves every two years. Bureau of the Census, Current Pop. Repts. Series P-20, No. 210, computed from Motor Vehicle Manuf. Ass'n $1972 \Lambda$ $\Lambda$ to. mobile Facts and Figures (1972). What would happen to people in West Virginia with "rural" cars who want to travel into any surrounding state, all of which have "urban" car regulation. People take motoring trips from one region to another and the average car changes ownership every three years.

53. Office of Science and Technology, Cumulative Regulatory Effects on tile Cost of Automotive Transportation 28 (1972). This estimate is a substantial under. statement of air pollution costs. Only the effects of certain types of emissions in pro. ducing certain categories of pollution damage were included in the analysis. Morcover, even disregarding these limitations, the health damage costs, which represented nearly ninety percent of total auto pollution damages, were grossly underestimated. The valite of human life and health includes not just (1) medical expenses and (2) lost carnings, but also (3) pain and suffering while ill, (4) costs peculiar to death, such as legal fees antil funeral expenses incurred now instead of later, the deceased's lost capacity to cnjoy personally selected assets more than his heirs, the deceased's employer's cost of training a replacement, and a loss of volunteer community services (e.g., in charity drives), (5) thic psychic cost of grief and loss of companionship suffered by relatives and friends of thic deceased or incapacitated, and (6) the "intrinsic" value of living to the deceasce, apart from the fruits of economic productivity already counted as lost carnings.

54. The domestic auto industry has been severcly criticized for devcloping the enginc system with the most disadvantageous outlook with regard to initial price, fitel cconoiny, maintenance and durability-the modified traditional internal combustion engine. $N A$ -

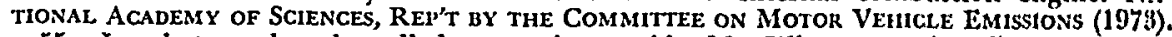

55. In what can best be called a gratuitous aside, Mr. Winter says it reflects our con. fusion over categories that occupational safety and health requirements are considered "enabling regulation" and not "safety regulation." Winter, n.25. It should be apparent that enabling regulation deals with the rules of the production process (which includes working conditions), while safety regulation relates to the buyer-seller exchange. 
lation. ${ }^{56}$ He acknowledges that these "may be good laws and may arguably be grounded in economic efficiency." 37 Our error, he contends, is to subsume them under the concept of "protect[ing] individuals in the productive process," "ss a rubric which, he says, might include the farm program and the Lockheed loan. ${ }^{59}$ Yet, unlike our original items, neither of these latter two can be justified on grounds of economic efficiency: Both are direct subsidies to preferred producers. The public policies encompassed by "enabling regulation" seek to establish equal rather than preferential treatment in the marketplace and to establish protections for anyone damaged (in certain defined ways) in the production process-which is quite different from conferring benefits on select groups. To leap to the conclusion that our category of enabling regulation is invalid, merely because some may erroneously invoke its rationale for protectionist purposes, is to deny the validity of all categorizations.

Mr. Winter's criticism of yardstick competition is similar to his criticism of enabling regulation: It might be abused. ${ }^{00}$ The original article never recommended that the government be allowed total discretion to call any action "yardstick enterprise." The result would be a blank check for boondoggles and waste. What we did argue for was a well-defined standard, which was that yardstick competition fulfill "a public need and, if properly circumscribed and wisely implemented, set an example for private enterprise." ${ }^{11}$ Yardstick enterprises would generally be required to be economically self-sufficient, without public subsidies. ${ }^{62}$ Public control would be tight, benefits would be progressively distributed, and a showing of the private sector's disinterest or incapacity to fulfill a "public need" would be a prerequisite to the government's endeavor. The examples we offered met this

56. See Tinter 899.900.

57. Winter 900. Mr. Winter balks, though, at justifying anti-discrimination laws on economic efficiency grounds. He asks why we should regulate the "psychic" preferences of discriminatory employers when we do not regulate the psychic preferences of consumers; i.e., "why not have a law against taking the color of a product into account:" Winter 902 [emphasis added]. The underscored words signal the key distinction. We allow consumers to consider "psychic," even irrational, criterin in selecting final products, because such freedom presumably maximizes their utility. But here we are considering irrational managerial choice of factor inputs (labor), an irrationality which we must correct to avoid inflating product prices due to labor incfficiency-not to mention the legal and social norm against racial discrimination.

58. Id. at 900 .

59. Id.

60. See id. at 900-01.

61. Nader 886.

62. Even in those rare cases where subsidies offset external economies uncapturable by the yard stick firm or enable declining cost industries to price at marginal cost, utilitarian principles would remain paramount. 
standard. The proposed SST subsidy, as concluded by Congress, did not.

Finally, Mr. Winter articulates his opposition to the proposed Consumer Protection Agency (CPA) which would advocate consumer inter. ests before federal agencies. He observes that "government by its very nature reacts to political pressure ... [and] will respond most favorably to those with the greatest ability and incentive to organize and press their claims." 63 It is difficult, therefore, to understand why he opposes enhancing consumers' ability to present their claims. Producers already have sizeable resources and well-developed organizations for this purpose. Consumers have neither. By tradition if not by statute, various departments of government represent special interests-e.g., the Department of Agriculture, farmers; the Department of Labor, workers; the Department of Commerce, businessmen. If these views are amply expressed, why does $\mathrm{Mr}$. Winter resist consumer representation? The CPA's purpose would be to make the adversary system work, and we would have expected support from those devoted to the legal process.

Far from supporting it, Mr. Winter again deploys hypothetical horribles to justify his opposition. First, he contends, the agency would fail to avoid the pitfalls of its predecessors. ${ }^{64} \mathrm{He}$ fails to see that the CPA, unlike a Pentagon or ICC, would confer no direct benefits, nor reward corporate acquisitiveness; it would only provide representation, before agencies and the courts. And unlike a CAB or FMC, with a decidedly producer clientele, a CPA would cater to consumers and hence develop a different orientation. Second, Mr. Winter argues that because consumer tastes vary, "representation is impossible." "or But consumers do have many common identifiable interests-e.g., economic efficiency, diversity of purchasing choices, avoidance of monopoly profits or consumer fraud, and optimal purchasing information. But if $\mathrm{Mr}$. Winter is merely saying that such an agency should wisely balance competing preferences and policy considerations, we would agree. Other agencies try to do so. Their lack of unitary mission or constituency, however, does not require that they cease to exist, which is where Mr. Winter's logic takes him.

Mr. Winter completely misses two key points about a CPA. Its mandate is not to decide, but to advocate. Other agencies would continue to decide; the CPA would only participate in a resuscitated adversary

\footnotetext{
63. Winter 893 .

64. Id. at 901 .

65. Id. at 902
} 
process. And its advocacy would seek not merely substantive changes but procedural reforms, such as readily available agency reports, more liberal confirmed standing requirements, in forma pauperis proceedings, and the awarding of attorneys' fees for successful petitioners. More able advocacy clearly benefits all consumers, whatever their tastes, middle class or poor.

Exploiting still another guise, Mr. Winter poses as a poverty lawyer representing "the most powerless in our society."00 His line of reasoning, which has a certain surface appeal, is that safety measures must increase product prices, which in turn must have a regressive impact on the poor much as an excise tax does. It is the poor, however, who are disproportionately the victims of externalities and who therefore would receive the largest share of the net reduction in externality costs that internalization, or its regulatory proxy, would produce. It is the poor who are most damaged by air pollution, ${ }^{07}$ accidents, ${ }^{08}$ leadbased paint poisoning, ${ }^{69}$ and nutritional deficiencies. ${ }^{70}$ The poor are also chiefly hurt by the market's failure to generate optimum product information. ${ }^{71}$ Studies of consumer fraud, including those of David Caplovitz, ${ }^{72}$ Philip Schrag ${ }^{73}$ and Jean Carper, ${ }^{74}$ describe in moving detail how everyday bilks erode the living standards of poor citizens. When you or I pay $\$ 600$ for a $\$ 200$ refrigerator, we are angry; when the same happens to the poor, someone goes hungry. Indeed, so disproportionate is their share of externalities that internalization would generally represent a progressive redistribution of income in favor of the poor..$^{75}$ It is the height of hypocrisy for critics of consumer reform to conscript the poor, who stand the most to gain, to defend their standard status quo positions. ${ }^{78}$

66. See id.

67. E.g., Craig \& Berlin, The Air of Poverly, Envirosment, Junc, 1971, at 2.

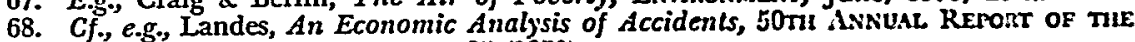
NAT'L BUREAU OF ECONOMiC RESEARCH 95 (1970).

69. Oberle, Lead Poisoning: A Preventable Childhood Disease of the Slums, 165 SCIENCE 991 (1969).

70. See the nutrition surveys cited note 28 supra.

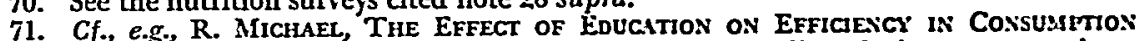
(Nat'1 Bureau of Economic Research, 1972). That some labeling devices seem to have been utilized disproportionately by middle and upper income consumers may demonstrate only that the labels were ineffectively constructed and displajed, as has almost universally been true of consumer labeling devices.

72. D. CAPLOVITZ, THE POOR PAY MfORE (1963).

73. P. SCHRAG, CounSEL FOR THE DECEYVED (1972).

74. J. CaRper, Not WITH A GUN (1973).

75. In the case of externalities whose burden is not borne disproportionately by the poor and whose internalization would have a regressive impact (e.g., arguably water pollution), internalization would still produce a net economic gain which could then be redistributed to the poor through the tax and welfare system.

76. It is perhaps pardonable to be mistaken about the income redistribution consequences of internalizing health, safety, and pollution costs and improving consumer 


\section{IV}

To answer one recurrent source of Mr. Winter's discontent: Yes, we do have "personal preferences." 77 Our fundamental premise is the maximization of consumer ivelfare. We oppose economic regulation which supplants a workably competitive market; but we favor costeffective health and safety regulation which supplements a market failing to protect consumers optimally. Despite Mr. Winter's persistent contentions to the contrary, these positions are in no way inconsistent.

For all of his question raising, Mr. Winter seems unconcerned with the possible real world results of his propositions. The issues here ultimately move beyond mere economic and legal analysis, to the human lives at stake. Would Mr. Winter object to Commerce Department standards for flammable fabrics, and if so, what does one say to children severely burned by their pajamas? Would he abolish the FDA? If so, how should society then cope with a pregnant woman who suffers from a drug's feticidal (fetus-killing) and teratogenic (fetus-deforming) effects, because the drug company failed to warn her of possible adverse reactions? Would he object to the newly created Product Safety Commission? And if so, must we simply assume that an annual 30,000 deaths, 110,000 permanent disabilities and 20 million injuries due to accidents associated with consumer products is the cost of progressive capitalism? ${ }^{78} \mathrm{Mr}$. Winter provides no answers to such questions; his proposals and protestations amount to a defense of producer sovereignty in a market which is mistakenly presumed to be selfcorrecting.

Happily, many of Mr. Winter's contentions are, in both senses of the word, academic. Notwithstanding Winter-like opponents of henlth and safety regulation, the FDA will monitor dangerous drugs, auto

product information, all measures which would increase aggregate consumer wclfarc, and especially the welfare of the poor. It is quite another matter, however, to accuse the consumer movement of moving beyond the above objectives and advocating that the law "can compel the production of "better" "and more costly products preferred by the upper-middle class, to the exclusion of "cheaper" in quality but less expensive items, preferred by the poor. Winter 902 . $\mathrm{Mr}$. Winter, who makes this broadside criticism without any evidence or example, accuses us of taking a position which we have never taken and fundamentally reject.

Mr. Winter also states that safety, anti-pollution and consumer information measures "must decrease output and in particular decrease the production of cheap, mass pro. duced goods" so important to the poor. Winter 902. No doubt, output, as measurced by GNP, would be reduced, but social welfare, a measure which includes the countervailing benefits of reduced pollution and accident damage and increased consumption cfficiency, would be advanced. Moreover, "the production of cheap mass produced goods" would "in particular" be least affected, since their relatively high economies of scalc could ab. sorb the increase in unit costs imposed by regulations to a greater cxtent than "quality" goods preferred by the middle and upper classes.

77. See, e.g., Winter 900-01.

78. Final Report of the National Committee on Product Safery 1 (1970). 
manufacturers will scramble to meet 1975 and 1976 pollution deadlines, the FTC will move against deceptive advertising, and the Product Safety Commission will soon begin its work. And despite the hypothetical haggling of anti-consumerists, the benefits of consumer legislation are becoming widely recognized. "The most frequently mentioned effects of consumerism," a life insurance official recently commented on a survey of small life insurance companies, "are better service and improved policy owner relations ... and a trend toward more frequent price benefit comparisons ...." If If industry has begun to see the light, can even Professor Winter be far behind?

79. Brain, The Life Insurance Outlook for 1973, BesT'S REviEw, Jan. 1973, at 56.57. 